\title{
Brazil's Cooperation with Sub-Saharan Africa in the Rural Sector
}

\section{The International Circulation of Instruments of Public Policy}

\author{
by
}

\author{
Carolina Milhorance de Castro
}

\begin{abstract}
South-South cooperation is grounded in the idea that partners from the developing world are well placed to propose solutions inspired by their own experiences. A study of the dynamics of the circulation of instruments of public policy framed in the agricultural sector between Brazil and Sub-Saharan Africa under the Lula administration (20032010) reveals that political entrepreneurs play a key role in the early transfer stages of this process and that a technical logic of policy transfer through South-South cooperation may pose important challenges to the later stages of reception and adaptation. A notion of complementarity between agribusiness and family farming that reflects recent governmental discourse has been influential in the formulation of initiatives.
\end{abstract}

A cooperação sul-com-sul se baseia na ideia de que os parceiros do mesmo mundo se situam bem para propor soluções inspiradas pela sua própria experiência. Um estudo da dinâmica de como se difundam os instrumentos das politicas públicas adotadas no setor agrícola entre o Brasil e os paises da África sub-saariana dos tempos da administraçõ do Presidente Lula (2003-2010) revela que os empresários públicas tiveram um papel chave nas etapas iniciais deste processo e que uma lógica técnica da transferència das políticas para tal cooperação sul-com-sul pode apresentar desafios importantes às etapas subsequentes da recepção e adaptação. Uma noção de que pode existir uma complementaridade entre os agronegócios e a agricultura familial - algo que se nota atualmente no discurso governamental - estaba influencial em formular os iniciativos.

Keywords: South-South cooperation, Brazil, Africa, Agriculture, Standardization

Interest in the emerging economies in the African continent has contributed to the continent's ongoing economic and social transformation through diversification of trade, investment and partnerships, and new forms of development cooperation (OECD et al., 2011). South-South cooperation, which since the mid-twentieth century has been consolidated as a strategy for the integration of the developing world, relies on the idea that partners from the developing and emerging world are familiar with development challenges and therefore well placed to propose solutions based on their own experiences. Brazilian engagement in Sub-Saharan Africa, particularly in the agricultural and rural sector, follows this reasoning, and instruments of the country's public policies tend to be transferred to African states through cooperation projects. Agriculture

Carolina Milhorance de Castro is a Ph.D candidate in political sciences at the University of Brasília $(\mathrm{UnB})$ and the French Center for Agriculture and Development (CIRAD) 
has been identified by Brazilian and African governments as a priority sector for this exchange. Brazil has become an agricultural power, an exporter of many raw materials and biofuel, and has shown great progress in implementation of policies relevant to food security. Its agricultural model-characterized by public policies supporting both family farming and export-oriented industrial agriculture-allows cooperation initiatives in both segments of the sector.

The diffusion, transposition, and convergence of public policies have been the objects of policy transfer studies (Delpeuch, 2008; Dolowitz and Marsh, 1996). These studies, mostly proposed as a heuristic framework (Benson and Jordan, 2011; Dolowitz and Marsh, 2012; Evans and Davies, 2002), have until recently focused on a subset of developed Western countries, particularly in Europe, with little attention being paid to the experiences of developing countries (Macaulay, 2007; Marsh and Sharman, 2009). The export of Brazilian agricultural policy instruments and the rationale behind it have been little examined (Perch et al., 2012), as has the notion of transfer's relying on similar physical and development conditions that is characteristic of South-South cooperation and prominent in Brazil-Africa cooperation. The mechanisms that forge transnational ties and open the way for the transfer of practices and institutions across borders also remain unclear. The study of these mechanisms involves examining the influence of actors and the establishment of configurations in the promotion of policy transfer (Ancelovici and Jenson, 2012).

The aim of this article is therefore to address the dynamics of cooperation and policy transfer in the agricultural sector between Brazil and Sub-Saharan Africa through an examination of the institutional construction of Brazilian cooperation policy under the Lula administration (2003-2010). The research focuses on the mechanisms of the early stages of the trajectory of transfer, conceptualized by Ancelovici and Jenson (2012) as the "standardization process" and dedicated to the selection of local practices and their translation into exportable abstractions. Drawing upon the public policy literature and upon firsthand data collected in various Brazilian public and private institutions, ${ }^{1}$ the article intends to demonstrate that political entrepreneurs located at the intersections of state and nonstate networks play a key role in the standardization process. Furthermore, it will suggest that a technical or "unproblematic" view of policy sharing through South-South cooperation may pose important challenges to the later stages of reception and adaptation. It will also attempt to assess the influence of the Brazilian dual agricultural model on the formulation of cooperation initiatives and shed light on the possibility of generalizing Brazilian agricultural and rural policies.

\section{BRAZIL'S NEW DRIVE FOR AFRICA: TRADE, POLITICAL DIALOGUE, AND "STRUCTURING COOPERATION"}

Despite many convergences in terms of interests, Brazilian policy for Africa has been characterized by discontinuous impulses. The current period, inaugurated by President Luis Inácio Lula da Silva in 2003, has been identified as the third wave of contemporary Brazilian relations with Africa (Hirst, 2010). These relations are promoted on the grounds of historical, racial, and sociocultural 
identity, representing the main referent of Brazilian South-South cooperation. Political discourse stresses the intention to settle a historical debt, but this effort has also been motivated by the possibility of acquiring prestige and influence by forming political coalitions among countries of the global South (Hirst, 2010).

Brazil-Africa relations have largely reflected the continent's postcolonial relations, although the influence of traditional aid partners is still relevant (OECD et al., 2011). Although emerging economies have been assembled into economic and political groups, their development strategies and foreign policy continue to be individual, differing with the sector, the type of goods traded, the technologies involved, and the underlying funding models (CSIS, 2010). Brazil, which benefited from substantial international aid in the postwar period, launched a platform for trade and cooperation with less developed countries in the 1960s based on the idea that the traditional aid system would be unable to meet the challenges of development (Vaz and Inoue, 2007). In confronting the problems of modernity and multiple dimensions of poverty, Brazil avoids terms such as "donor" and "beneficiary," preferring the concept of "horizontal cooperation" (Rowlands, 2008).

In the 1960s, Brazil's "independent foreign policy" advocated nonautomatic alignment with the cold war powers and the fight against underdevelopment. This drive represented the first wave of Brazilian engagement in Africa, illustrated by the opening of embassies in independent countries (Ghana, Nigeria, and Senegal) and political support for colonial liberation movements. A new strategy, described as the second wave, was employed during the détente of the cold war. Since then Brazil has chosen the path of an ecumenical and responsible pragmatism, strengthening its relations with African and communist countries. Consequently, this movement has been followed by a rupture of Brazil-Portugal relations. On the economic front, several companies have been involved, and between 1972 and 1981 the proportion of trade with Africa increased from 3 percent to 9 percent of Brazil's total trade (Hirst, 2010). This cooperation lost momentum in the subsequent decades. Following the creation of the Community of Portuguese-speaking Countries, the aforementioned cooperation was reinforced in 1996, and efforts were largely concentrated in these countries.

The third wave of Brazil-Africa relations has benefited from greater financial resources and political effort. For instance, technical cooperation initiatives increased by 250 percent from 2008 to 2009 (MRE/ABC, 2011), although data on the resources employed are imprecise. In fact, Brazilian cooperation policy gained notoriety under the Lula administration. Based on a South-South cooperation strategy, some of its foundations were the 1995 Bandung Conference and the 1978 and 1997 action plans of Buenos Aires and San José, which promoted horizontal forms of cooperation and the symbolic replacement of the expression "technical assistance" by "technical cooperation."

Technical cooperation is one of the main instruments of these Brazilian initiatives, endorsed as a means to increase training and employment of local labor (MRE/ABC, 2011). These initiatives, termed "structuring cooperation," combine human resources and institutional development (Buss and Ferreira, 2010). Importantly, the country adopts a holistic approach to international cooperation in which trade and investment are seen as legitimate and effective 
means of development (Haibin, 2010). However, this approach, as reiterated by President Lula himself (IPEA/ABC, 2010), is a model under construction.

Accordingly, Brazil has built trust and recognition in the South without alienating the North. Its expertise in the fight against hunger and poverty has attracted the interest of developing countries. At the same time, its commitment to multilateralism combined with the shared values of some traditional donors and the interest these donors show in maintaining strategic relations with this emerging economy make the country a potential partner for triangular cooperation. This strategy represents a step toward multilateral and affirmative action (Lopes, 2008). One cannot, however, ignore the political facet of South-South cooperation, one of the main objectives of which is to reform the international order and the economic system by strengthening bilateral relations and establishing coalitions in the multilateral arena (Pino, 2009).

Political relations have diversified beyond the Portuguese-speaking countries. In all, 19 Brazilian embassies were opened, and President Lula participated in 10 missions to the continent (in 23 countries), always accompanied by representatives of the private sector. An office of the Empresa Brasileira de Pesquisa Agropecuária (Brazilian Agricultural Research Corporation-EMBRAPA) has been established in Accra, Ghana. Foreign trade and the participation of Brazilian companies have also intensified in the past decade. Trade multiplied six times between 2000 and 2008 (from US $\$ 4.2$ billion to US $\$ 25.9$ billion), and, despite an inflection in 2009 as a consequence of the global financial crisis (Ncube, Lufumpa, and Vencatachellum, 2011), 2010 witnessed an increase in trade (US $\$ 20$ billion) (OECD et al., 2011). Brazil is the only developing country with which the African continent has a large surplus (OECD et al., 2011).

In addition to the Ministry of Foreign Affairs, the Banco Nacional de Desenvolvimento Econômico e Social (National Bank for Economic and Social Development-BNDES) has a key role in promoting the presence of Brazilian capital on the continent. Incentives for Brazilian companies exporting to Africa reached $\mathrm{R} \$ 477$ million in 2008 and $\mathrm{R} \$ 649$ million in 2009 (PDP, 2010). There are no official data regarding foreign direct investment, but it is estimated at US\$10 billion in 2009 (Ncube et. al, 2011).

The recent strengthening of Brazilian engagement in Africa reflects, in a large part, the country's own development model, combining a dynamic private sector with support from the BNDES and other public institutions. Policy dialogue, technical cooperation, investment, and trade represent complementary dimensions of Brazil's new drive for Africa.

\section{THE INTERMEDIATE STATE}

The inclusion of the social agenda as a major topic of Brazilian foreign policy under the Lula administration was one of the first and most important innovations. In the context of South-South cooperation, this drive may be understood in terms of the country's aspiration to what one might call an intermediate international role (Lima and Hirst, 2006). Brazil has demonstrated the intention to expand its roles and responsibilities in regional politics, Third World agendas, and multilateral institutions (Lima and Hirst, 2006). Although there is no 
agreement on a definition of an intermediate state, it generally includes at least one of the following factors: material capabilities, self-perception, regional influence, and recognition by other states (Lima, 2005; Marques, 2005; SouleKohndou, 2010). The category may in fact translate two international identities, one related to the world of politics and defined by Keohane (1969) as a systemaffecting state and the other related to global economics and defined as an emerging market. The former includes countries that have relatively limited resources and capabilities in comparison with those of the great powers but show an assertive international profile and make use of multilateral arenas. The latter are large countries on the periphery that have implemented neoliberal reforms and whose macroeconomic credibility and stability are highly valued in a globalized world. According to Lima (2005), intermediate states, including Brazil, combine the two international roles of system-affecting state and great emerging market.

Aspects less tangible than material capabilities such as diplomatic tradition, historical factors, ideological influence, and relational dimensions are considered equally important in ensuring that a country will play a role in international relations (Lima, 2005; Soule-Kohndou, 2010). In this context, Brazil's international image as intermediate state also relies on its capacity for persuasion and its credibility, a form of soft power $^{2}$ (Lima, 2005). Lima (2005) shows that the source of the credibility of a country's foreign policy in different historical periods leads to different patterns of conduct in the search for international recognition (e.g., strategic alignment with the United States, internationalism, or globalism). Its credibility under the Lula administration is related to aspects such as democratic stability, economic growth, and the ability to act as a model in terms of social policies.

As Inoue and Vaz (2012) suggest, Brazilian cooperation is not completely divorced from national, subnational, or sectoral interests or from its broader foreign policy objectives and power shifts in the international system.

\section{AGRICULTURE AT THE CENTER OF BRAZIL-AFRICA DEVELOPMENT COOPERATION}

\section{INTERNATIONAL RECOGNITION OF PUBLIC POLICIES}

Brazil has prominently augmented its agricultural production over the past decade, a result achieved with lower subsidies compared with OECD countries (Economist, 2010). At the same time, the policies adopted by the Lula administration have had a pronounced impact on food security outcomes, enabling the achievement of the relevant United Nations Millennium Development Goals five years before the deadline (IPEA/ABC, 2010). EMBRAPA has been the protagonist of a major technological breakthrough that has enabled the expansion of the agricultural frontier into previously unexplored areas and an increase in productivity. This performance has been linked to the development of new technologies and crops adapted to different soil types, the modernization of agricultural equipment, and consequent productivity gains. Thus the country has shown significant progress in large-scale export agriculture as well as small-scale family farming. 
At the same time, many African countries are net food and energy importers, and agriculture remains the main source of employment and export revenue, representing 30 percent of the gross domestic product of Sub-Saharan Africa (World Bank/IPEA, 2011). In 2003, the Comprehensive Africa Agriculture Development Program was launched in the framework of the African Union with the aim of integrating cooperation initiatives and investment. Policy debate in preceding decades had focused on market liberalization and opposition to export subsidies. This debate was replaced in the 2000s with an emphasis on the internal dimensions of development, in which agricultural investment and policy again had priority on the agenda after years of structural adjustment and the dismantling of the state. In this context and in a situation of food crisis, Brazilian and African governments have identified agriculture as a priority area for exchange during the meeting held in Brasilia among Brazilian and African ministers of agriculture in 2010.

The selection of a former Brazilian minister, Graziano da Silva, as head of the Food and Agriculture Organization (FAO) was an important outcome of the country's strategy of assertion in international institutions. It also initiated a discussion of the organization's role in supporting the formulation of public policies, and, according to Silva, the potential for Brazilian cooperation in agriculture is also expressed in these terms (Opera Mundi, 2011). Therefore, the recent spate of cooperation in agriculture is directly linked to international expectations in the context of the food crisis and the return of agriculture to the center of the development debate, as well as to an assertive Brazilian effort in promoting its agricultural experience internationally.

\section{BRAZIL'S DUAL AGRICULTURAL SECTOR}

The modernization of Brazilian agriculture was launched in the 1950s. The development of an agro-industrial complex depended on government incentives, particularly rural credit and fiscal incentives (Teixeira, 2005). The role of the Ministry of Agriculture, Livestock, and Supply was critical, and the formation of EMBRAPA allowed the development and transfer of appropriate technologies to different regions and soil and climatic conditions within the country. From an economic point of view, the modernization of agriculture has contributed to an increase in productivity and exports, as well as to regional integration in a national context. However, from a social and environmental point of view, modern inputs and equipment have aggravated environmental degradation and contributed to the rise of unemployment in rural zones (so-called conservative modernization) (Teixeira, 2005). Agribusiness helped achieve macroeconomic control and a positive balance of payments during the economic stagnation of the 1980s. Policies regarding the exchange rate for exports, minimum prices for agricultural products, and technological development for an increase in productivity have helped develop agriculture in a macroeconomic environment that was hostile both domestic and externally.

Social movements and farming groups were strengthened after the end of the military regime in the late 1980s. Land occupation claims for agrarian reform and demands for credit programs specific to small farmers became frequent. In this context, family farming emerged as a "concept-synthesis" featuring an 
entire rural sector (Porto and Siqueira, 1997), and it gained political space when conservative modernization failed in social terms (Bianchini, 2005). The National Family Farming Program was the first government program aimed at family farming and represented the legitimization of the concept by the Brazilian state (Schneider, 2003). This program was followed by the creation of the Ministry of Agrarian Development.

Several writers (Delgado, 2010; Sabourin, 2007; Schneider, 2003) argue that the organization of social actors and their recognition by the state led to a general conception of the presence of "two agricultures": capitalist agriculture and small peasant production. The creation of the Ministry of Agrarian Development and the implementation of the Programa de Fortalecimento da Agricultura Familiar (National Family Farming Program-PRONAF) helped to crystallize this representation. This dichotomy in the perception of the Brazilian agrarian sector has also been legitimized by other public policies: the Rural Assurance Program ensures resources for commercial agriculture at the expense of family farming, which is directly assisted by PRONAF. Nevertheless, this controversy has contaminated the debate over a policy adapted to the diversity of family farmers in Brazil (Sabourin, 2007).

During the Lula administration, the amount of resources allocated to family farming more than tripled, as did the number of farmers benefiting from credit (Delgado, 2010). Additionally, there has been a deeper institutionalization of political mechanisms through the adoption of new legal instruments. The importance of agribusiness in the Brazilian economy and politics, however, given its strategic role in the balance of payments and despite fundamental changes in foreign policy, remains unchanged, and agribusiness continues to set the agenda for trade negotiations (Machado, 2009). Since 2005, export policy and international negotiations have been carried out by the Ministry of Agriculture, Livestock, and Supply. The creation of sectorial chambers within this ministry has contributed to assembling private-sector representatives around the formulation of agricultural public policy.

In recent times, governmental efforts have been directed toward promoting a political strategy of "peaceful coexistence" between the two agricultural models (Christoffoli, 2007). President Lula has reaffirmed in several speeches that family farming can coexist with agribusiness (in Brasília September 30, 2005, and July 24, 2006, and in Maringá September 23, 2010), including the following speech in Cape Verde (Silva, 2010, my free translation):

Brazil is an African partner. ... Our soils, our climates, and our genetic resources also bring us together. The Brazilian cerrado, where dynamic agriculture and livestock are developed, shows strong similarities with the African savannah. In many countries of the continent, including that of ECOWAS [Economic Commission of West African States], we are able to reproduce the Brazilian agricultural revolution. We have converted unproductive lands into fertile agricultural areas, thanks to a combination of applied agrarian research and a set of public policies. We have produced a harmonious coexistence of a modern entrepreneurial agriculture and a robust family farming sector. Small-scale farmers' production accounts for 10 percent of our GDP. It creates millions of jobs and provides 70 percent of the food we consume in Brazil. It increases revenue in rural areas and multiplies its effects in consumption. 
The "coexistence" of family farming and agribusiness is to rely on a legal framework and public policies supporting two agricultures (food production and production of commodities for export). In this context, the family farming sector has also been characterized as "modern," "efficient," and "the food producer for the country" (Picolotto, 2006). Several studies show that the National Family Farming Program, under individual credits or subsidies for collectively owned equipment, has mostly benefited capital-intensive farming and farming connected with the banking network, particularly in the Southern region (Abramovay and Piketty, 2005; Abramovay and Veiga, 1999; Carneiro, 1997; IBASE, 1999; Sabourin, 2007). Change has also been observed in the implementation of the More Food Program, which supports both large cooperatives and industrial family farms. Other programs, such as the Food Acquisition Program, have contributed to the integration of public actions aimed at intersectorality. This program is coordinated by a group of ministries and combines mechanisms of support for agricultural production with differentiated prices for family farmers. Simultaneously, the More Food Program focuses on multiple dimensions of the agrifood chain. Finally, the 2003 creation of the National Food and Nutritional Security Council has ensured greater visibility to the distinctive demands of family farming.

\section{THE INSTITUTIONAL FRAMEWORK OF BRAZILIAN COOPERATION}

Policy transfer is now common currency in political studies and public policy analysis, and research in this field has arguably entered a more mature phase. Recent works have engaged with the role of political structures in shaping transfer, for example, in more multilevel institutional settings (Benson and Jordan, 2011). In the early 1990s James Rosenau (1990) had already suggested that only multilevel theory seemed capable of coping with the puzzles posed by the "turbulence" roiling the actors and structures of world politics, acknowledging the complexities of the current scene. Rosenau's frequent theme has been the challenge of achieving governance along the domestic-foreign frontier (Rosenau, 1997). He highlights the need for analysis of the way the dynamics of fragmentation are fostering new structures and processes, arguing that the combination of internal and external dynamics generates "simultaneous tendencies toward globalization and localization, toward more extensive integration across national boundaries and more pervasive fragmentation within national boundaries, toward a relocation of authority 'outward' to transnational entities and 'inward' to subnational groups" (Rosenau, 1990: 350). Brazil is driven by a complex set of actors and forces in providing international development cooperation. A closer look at the actors involved, the underlying process, and the ideational aspects of Brazilian cooperation may provide a broader understanding of the interests and features of a political enterprise that is currently characterized by segmentation and multipolarity.

In addition to the Brazilian Cooperation Agency, several institutions participate in the agricultural agenda: the Ministry of Agriculture, Livestock, and Supply, the Ministry of Agrarian Development, the Ministry of Social Development and Fight against Hunger, the Ministry of Education, EMBRAPA, the National Supply Company, the Agency for Technical Assistance and Rural 
Extension, and the National Rural Education Service. Public universities are involved in designing some of the initiatives, and some nongovernmental organizations are attempting to monitor the implementation of these initiatives. The Ministry of Development, Industry, and Foreign Trade encourages trade missions, export financing, and investment in Africa while contributing to a convergence of interests between the public and the private sector (Hirst, 2010).

EMBRAPA has a unique role in this arrangement, and until 2008 it underwrote the formulation and implementation of approximately 95 percent of Brazilian cooperation initiatives in agriculture (Magalhães, 2008). EMBRAPAAfrica aims to provide African countries with Brazilian technologies, concentrating on partnerships with international organizations and response to private-sector demands and the requests of the Ministry of Foreign Affairs. The office also assists African entrepreneurs interested in Brazilian technologies as well as Brazilian entrepreneurs seeking an African foray. Therefore, the institution contributes to the agreements signed between African governments and Brazil as the facilitator of foreign policy in the agricultural sector. Technology transfer may still be associated with the creation of markets for machinery, equipment, and supplies.

There is also concern regarding the structuring of programs economically capable of engaging the African private sector and creating business opportunities. Feasibility studies of biofuel production conducted by the BNDES develop business plans based on this notion. The same perspective is perceived in projects implemented in Mozambique and Mali. Brazilian private-sector engagement is encouraged not only by export credits and partnerships with EMBRAPA-Africa but also through the Ministry of Foreign Affairs. Thus, while Brazilian cooperative efforts are essentially government-driven, private actors play an important role.

At the same time, direct participation by the civil society in cooperation projects remains relatively weak. One of the few examples is the project coordinated by the Brazilian Institute of Social and Economic Analysis aimed at the establishment of community seed banks and the use of native seeds in Southern Africa. Even so, several organizations have been monitoring Brazilian-led projects on the African continent under transnational networks. They bring together, for instance, Mozambican, Brazilian, and Japanese institutions and social movements, shedding light on critical aspects of the agricultural project (ProSavana) in the Nacala Corridor in Mozambique. Other initiatives, such as the Civil Society Forum of the Community of Portuguese-speaking Countries and the network led by Brazilian Association of NGOs, advocate for the establishment of a mechanism for monitoring and evaluating cooperation policy. Decentralized cooperation initiatives such as the Decentralized South-South Technical Cooperation Program could be cited as an example. ${ }^{4}$

Brazilian foreign policy is a result of coalitions of domestic and international actors with various degrees of influence. In this context, some of the characteristics of this period are the gradual pluralization of actors and the politicization of foreign policy (Hirst, Lima, and Pinheiro, 2010). Studies of the international circulation of public policy have also highlighted state fragmentation. Infrastate actors have asymmetric resources and are not necessarily 
involved in all stages of the transfer process. These actors generally have the autonomy to lead international cooperation initiatives in their sector according to their own conceptions of the "general interest" (Slaughter, 2002). However, a particular category of actors is central in these studies: those who mobilize in favor of the generalization of a policy or model, providing information and persuading the political and administrative decision makers. Ancelovici and Jenson (2012) emphasize the importance of political agents in the process of converting ideas and practices into local "standard models," what they call the "standardization process."

Until recently, Brazilian cooperation in agriculture took place almost exclusively through EMBRAPA. These initiatives consisted of knowledge and technology transfer in the fields that enabled Brazil to become a major producer and exporter of agricultural products. However, with the recent engagement of the Ministry of Agrarian Development and the introduction of programs geared to family farming into the portfolio of projects, the content of cooperation has been amended. The Brazil-Africa dialogue has also contributed to the reinforcement of the role of this ministry.

\section{THE INTERNATIONALIZATION OF AGRICULTURAL POLICY}

The intervention instrument that Brazilian officials call the "structuring of projects" has been conceived from a long-term perspective. Given the economic and territorial disparities between Brazil and some African countries, these projects are implemented in partnership with regional organizations envisioning the creation of economies of scale (Goes, Patriota, and Tiburcio, 2010; World Bank/IPEA, 2011). The US\$5.26 million Cotton Four Project aims to support the development of the cotton sector in Benin, Burkina Faso, Chad, and Mali. In Senegal a US\$2.4 million project aims to support the development of nationwide rice cultivation. In addition to structuring projects, Brazil implements initiatives concentrating on training for agricultural research and on public policies such as the distribution of agricultural products. Three large projects coordinated by EMBRAPA in Mozambique include adapting Brazilian agricultural varieties and technologies, reinforcing research institutions, and building capacity (ProSavana, Plataforma, and ProAlimentos). They promote trilateral cooperation engaging the U.S. Agency for International Development and the Japan International Cooperation Agency.

The Food Acquisition Program brings together a series of pilot projects in an effort to create institutional markets for family farmers in different African macroregions. This program is implemented in collaboration with the FAO and the World Food Program. The More Food Program is a financing mechanism for purchasing Brazilian agricultural machinery and equipment. The Chamber of Foreign Trade has approved a credit line of US\$640 million to finance exports (World Bank/IPEA, 2011), coupled with technical cooperation activities. The private sector is also cautiously increasing its presence on African soil. The recent joint venture between Brazil's Pinesso and Sudan's Agadi, focusing on the production of cotton and soybeans in Sudan, is an example, and another is the BNDES's funding of an ethanol plant in Angola and a recently opened 
office in South Africa. Furthermore, the Brazil-Africa Agricultural Innovation Marketplace brings together African and Brazilian experts in cooperative agricultural projects on the basis of a trilateral arrangement in which US $\$ 3$ million has already been invested. Some of these initiatives are taking place on home turf. For instance, staff training initiatives, whether in the Center for Research and Training in Tropical Agriculture or the University of Luso-Afro-Brazilian Integration, are located in the semiarid Brazilian Northeast.

Brazil's public policies in agriculture are actually the result of a historical dispute between two different views of development. The Lula administration has endeavored to create an institutional environment that communicates the idea of peaceful coexistence of agribusiness and family farming. It was therefore the notion of complementarity that was chosen to guide Brazilian intervention on African soil, rather than the institutional dichotomy or the dual model. This strategy does not necessarily reflect the diversity of the political debate in Brazil but represents the Presidency's recent synthesis of that debate.

The ProSavana Program is supposedly aimed at increasing food security by increasing the productivity of smallholders while augmenting exportable surplus through technical assistance to agribusinesses. It is based on a dual strategy of promoting, within the same institutional and programmatic framework, small/medium-sized farmers and large agribusinesses oriented to international markets. This initiative has been associated with the improvement of transportation infrastructure (the construction of highways in the Nacala Corridor by the Brazilian mining company Vale). The More Food Program goes beyond specific training initiatives to focus on the formulation of public policy and has been associated with technical and economic cooperation. This project also incorporates the equipment and agricultural inputs industry, as well as technical cooperation for the production phase. The Food Acquisition Program combines production and marketing tools and focuses simultaneously on multiple dimensions of the agrifood chain. The program ensures the demand for and distribution of the agricultural products of family farmers.

In fact, the agricultural model being exported is not a stable model in Brazilian society. It is the source of multiple disputes over public policy, financial support, and symbolic value. But cooperation initiatives tend to reproduce policies of support for family farming without reducing the importance of agribusiness. Therefore, the latter retains its legitimacy as an instrument of national development, and this contributes to the persistence of agribusiness as one of the major beneficiaries of Brazilian public policy. Until recently, cooperation initiatives concentrated on technical cooperation aimed at the development of a modern agricultural sector capable of producing exportable surpluses. Only after the 2008 food crisis were Brazilian family farming programs included in the cooperation portfolio.

\section{THE STANDARDIZATION OF PUBLIC POLICIES}

South-South cooperation is based on the similarities of partners in an effort to simplify and increase the effectiveness of adaptation of technological and political solutions. The preliminary stage of a policy transfer is identified as the 
conversion of local ideas and practices into a "standard model." The configuration of this model before its diffusion into other environments is considered an important step, given that not all ideas and practices become standards. The decision to promote one policy or institution rather than another depends on a political effort in which certain actors acquire the authority to represent a standard model. This concept often implies a replacement of local practices with widely accepted standards and norms, involving a process of reinterpretation to enable cooperation among different actors (Ancelovici and Jenson, 2012). Actors characterized as "transfer entrepreneurs" or "transfer agents" invest and mobilize for the generalization of policies or models that they consider deserving of dissemination. Ancelovici and Jenson (2012) identify three potentially robust mechanisms as central to the process of standardization: certification, disembedding, and framing. ${ }^{3}$ This process highlights the way in which ideas and practices are identified in their milieu by policy makers, NGOs, and international actors and then shaped as a generic construct that can be exported to another environment.

Tilly and Tarrow (2008) say that certification occurs when an external authority recognizes a political actor and his claims. It is assumed, therefore, that one actor is able to certify another, but this may also mean legitimization of a number of practices. In the Brazilian case, the performance of agriculture over the past decade has been clearly recognized, ensuring international legitimacy, but the political effort of the Lula administration has had a significant influence on the certification of Brazilian programs and technologies by international actors such as the United Nations Development Program, the FAO, and the African governments themselves. Brazil achieved the UN's millennial goals with regard to food security ahead of the deadline through effective policy making. Diplomatic efforts at disseminating the results of these policies and promoting them as potential South-South cooperation lesson-learning instruments, presidential discourses during official visits, and collaboration with those international organizations have made the Brazilian experience very popular. Furthermore, Graziano da Silva's election as head of the FAO is testimony to the international and African recognition of his policies.

Subsequently, in order to become an object of international transfer the public policies selected by transfer agents and certified by international actors go through a process of disembedding. This process requires prior political and cognitive effort (Ancelovici and Jenson, 2012) and involves the "decontextualization" of certain practices, ideas, or institutions-their separation from their social, cultural, economic, and historical settings-to reduce potential obstacles to transposition. Agribusiness has been one of the greatest beneficiaries of rural credits and public policies in Brazil, contributing not only to control over the balance of payments but also to rural unemployment, social exclusion, and environmental impacts. These issues have not been clearly addressed by cooperation initiatives. The notion of complementarity between agribusiness and family farming also contributes to the decontextualization of programs, reducing possible obstacles to EMBRAPA initiatives and criticisms with regard to the international interests of Brazilian agribusiness. Nonetheless, it is worth recalling that peaceful coexistence is also the basis of Brazil's own political efforts and discourse even though it overlooks persistent domestic conflict. 
Similarly, political agents are critical to the process of converting ideas and practices into standard models capable of being transferred. In this context, the mechanism of political framing refers to defining problems, simplifying situations and experiences, and proposing solutions. Thus, agents of Brazilian cooperation frame and showcase selected initiatives as instruments of rural development and poverty reduction and identify African countries as partners rather than beneficiaries. In a historic moment of affirmation of post-neoliberal policies and a highlight of South-South cooperation, the adoption of the principles used by Brazilian diplomacy (demand-driven, no conditionalities, respect for autonomy, nonintervention, horizontal collaboration) seems appropriate (Ancelovici and Jenson, 2012). Furthermore, the programs that are prioritized for implementation in African countries promote the notion of productive and entrepreneurial family farming. This follows the reframing of assistance policies for family farming and their replacement by the idea of modern intersectoral policies.

\section{CHALLENGES OF THE INTERNATIONAL CIRCULATION OF POLICY INSTRUMENTS}

This article has focused on the first stages of policy transfer rather than aiming to analyze the implications of this process for the importing environments. Nevertheless, some of its challenges can already be acknowledged. Similarities are the center of political discourse promoting Brazil-Africa cooperation. As Cabral (2011) argues, it is credible that agro-climatic similarities with some African countries simplify the exchange of experiences in the agricultural field. Shared language with Portuguese-speaking countries may facilitate these exchanges. However, the similarities between Brazil and African countries are sometimes overestimated, failing to account for the limited influence of African descendants on Brazilian political institutions. Certain instances also oversimplify the particularities of some African contexts. The construction of a national identity founded on mestizaje and "racial democracy" discourse (see Freyre, 1933) FREYRE, Gilberto [1933] (1971). Casa-Grande e senzala. Rio de Janeiro: Aguilar. posed a major challenge to Brazilian racial movement. And, despite the historical ties, the society's information about Africa is questionable.

Cabral (2011) discusses the "transferability" of state-civil-society dynamics, arguing that the idea that the Brazilian public policies are easily transferable to the African context follows a technical logic that does not take into account the social trajectory of these policies. Dowbor (2011) argues that a bridge has been built between the universe of intellectuals and that of the administration and the private sector in Brazil. However, a number of measures, such as feasibility studies and coordination with African national and regional agricultural plans and the recent engagement of civil society members with the Food Acquisition Program, contribute to smooth adaptation. Some project officers (in the Ministry of Social Development and EMBRAPA) draw attention to the fact that Brazil is aiming to share its experience with specific instruments of public policy and not entire national programs. 
Dolowitz and Marsh (1996) have pointed to the importance of accounting for the way in which problems are socially constructed and suggested that this intersubjectivity might determine the source of potential solutions. Benson and Jordan (2011) point to the existence of a study of transfer in more constructivist terms. Thus a sociological institutional perspective could be instructive in explaining the international transfer and adoption of Brazilian public policies.

There are also other issues regarding the selection of experiences to be transferred. The development of the cerrado region in Brazil is, for instance, considered a great success in technological and economic terms. However, social movements emphasize its social and environmental impacts, and these are issues that should be recognized and critically addressed. Sharing the Brazilian biofuel experience is also questionable when it comes to adaptation, since the development of this sector relied on a strong governmental strategy of stimulus, solid legal frameworks, pricing regulations, and public financing of agricultural production. Thus the possible development of this sector in African countries must take these structural aspects into account.

EMBRAPA-Mozambique describes its technology transfer policy as follows: "The focus is on the institutions as well as the local scientific community" (interview, March 28, 2012). Diplomats argue for a real knowledge transfer in which partners are able to replicate the knowledge acquired in a similar context of limitations. At the same time, an organizational transfer such as institutional strengthening of Mozambique's Institute of Agricultural Research by EMBRAPA is innovative in that it removes, adjusts, or renews components of the original model (Westney, 1987).

These aspects should be addressed by further analysis that details the process of adaptation of shared policies. Other aspects that could be clarified by further analysis include the idea of establishing a "policy market" in which international cooperation is not necessarily unidirectional. This could support a circulatory conception of policies, based on the co-construction of ideas and instruments in multiple arenas.

\section{CONCLUSION}

South-South cooperation is based on the idea that partner countries are well placed to propose solutions inspired by their own experiences. In the first phase, Brazilian cooperation initiatives in agriculture are focused on EMBRAPA's training and transfer of technological solutions to increase productivity under similar soil and climatic conditions. Recently, assistance in the formulation of public policies on family farming has also been incorporated. Another striking feature of some cooperation initiatives is their concern for commercial aspects. Although Brazilian engagement in Africa seems dependent on governmental efforts, the dynamics of public-private partnerships in Brazilian agricultural policies are reproduced in cooperation strategy. Thus the transfer of technology and public policies and the engagement of the private sector are important aspects of future Brazil-Africa relations in agriculture. 
These initiatives follow an overall discourse of complementarity between agribusiness and family farming. Cooperation policy also underlines governmental efforts to create a national institutional environment that will promote the peaceful coexistence of this duality. In spite of Brazil's historical and institutional dichotomy in the agricultural sector, it is the notion of complementarity that has been endorsed in high-level public policy dialogue with Africa. Brazilian diplomacy has repeatedly stressed this aspect, and some of the programs implemented on the African continent support both small/mediumsized farmers and large agribusiness oriented to international markets. However, the Brazilian civil society actors that are increasingly participating in foreign policy debates often point to this contradiction in the country's international engagement.

Brazilian cooperation is driven by a complex set of actors, forces, and motivations. The decision to undertake it was made by Lula and his diplomatic corps. The concept of standardization contributes to an understanding of the process of identification and transformation of those policies into exportable practices and of the role of transfer agents. Public policies that have been disembedded from their original environment and framed as modern intersectoral policies for entrepreneurial agriculture and as instruments of South-South lesson-learning are subsequently legitimized by international actors and organizations. Indeed, the choice of an example of policy transfer in South-South cooperation has been useful in problematizing the political aspect and the discursive smoothness of a transfer between developing and emerging countries. This process has been important in asserting Brazilian soft power and the country's self- and international recognition as an intermediate state. This perspective in terms of power imbalances is not incompatible with that of mutual gains and cooperation.

More empirical research is needed to gauge the impact of this policy in the field, and more analysis of the processes and implications of this policy transfer will be necessary to clarify the role of African actors in the construction of demand for cooperation with Brazil. This could shed light on the circulatory aspect of policy transfer, assuming that the purpose of transfer is not necessarily an authentic reproduction of original models but the development of a concerted response to a specific political problem. In this sense, concerns about uninformed or even inappropriate transfer should be evaluated, along with the role of endogenous innovation. The innovations and possible transformations provided by political and economic relations between Brazil and Africa should be the object of further analysis.

New state and private actors are likely to transform both the mechanisms of the international development cooperation system and the process of formulating national policies.

\section{NOTES}

1. Interviews and/or semistructured questionnaires with 50 persons from Brazilian public institutions, Brazilian embassies in Africa, private-sector associations, and nongovernmental organizations.

2. Soft power can be understood as the ability to seduce other actors by the legitimacy of one's policies and the values they endorse (see Nye, 2004). 
3. The Family Farming Law (No. 11.326/2006), the Food and Nutritional Security Law (No. 11.346/2006), and the Technical Assistance Law (No.12.188/2010).

4. "Programa de Cooperação Sul-Sul divulga resultado da segunda chamada" http://www4. planalto.gov.br/saf-projetos.

\section{REFERENCES}

Abramovay, Ricardo and Marie Gabrielle Piketty

2005 "Politique de crédit du programme d'appui à l'agriculture familiale (Pronaf): résultats et limites de l'expérience brésilienne dans les années 1990." Cahiers Agricultures 1 (14): 25-29.

Abramovay, Ricardo and José Eli da Veiga

1999 Novas instituições para o desenvolvimento rural: O caso do Programa de Fortalecimento da Agricultura Familiar (PRONAF). Brasília: FIPE/IPEA Nacional.

Ancelovici, M. and J. Jenson

2012 "La standardisation et les mécanismes du transfert transnational." Gouvernement et Action Publique 1: 37-58.

Antoniazzi, L.

2012 “Brasil e África parceiros no desenvolvimento agrícola sustentável." February 27. http:// www.redeagro.org.br/artigo-desenvolvimento-rural/619-brasil-e-africa-parceirosno-desenvolvimento-agricola-sustentavel (accessed May 2012).

AT (Ateliers de la Terre)

2012 "L'Afrique: fer de lance de l'innovation durable?" April 29. http://www.planetworkshops. $\mathrm{org} / \mathrm{fr} / \mathrm{post} / 129 /$ l-afrique-fer-de-lance-de-l-innovation-durable.html (accessed May 2012).

Benson, D. and A. Jordan

2011 "What have we learned from policy transfer research? Dolowitz and Marsh revisited." Political Studies Review 9: 366-378.

Bianchini, V.

2005 "Políticas diferenciadas para a agricultura familia: em busca do desenvolvimento rural sustentável." Cadernos do CEAM 5: 81-98.

Buss, P. M. and J. R. Ferreira

2010 "Health diplomacy and South-South cooperation: the experiences of UNASUR Salud and CPLP's Strategic Plan for Cooperation In Health." Revista Eletrônica de Comunicação, Informação e Inovaçãp em Saude 4: 99-110.

Cabral, L.

2011 Cooperação Brasil-África para o desenvolvimento: Caracterização, tendências e desafios. Rio de Janeiro: Cindes.

Carneiro, Maria José

1997 "Política pública e agricultura familiar: uma leitura do PRONAF." Estudos Sociedade e Agricultura 8: 70-82.

Christoffoli, P.

2007 "A evolução recente da questão agrária e os limites das políticas públicas do governo Lula para o meio rural," pp. 113-154 in Faculdade de Direito, Programa de Pós Graduação em Direito da UFPR, Estudos de direito cooperativo e cidadania. Curitiba: UFPR.

CSIS (Center for Strategic and International Studies) 2010 Key Players in Global Health: How Brazil, Russia, India, China, and South Africa Are Influencing the Game. Washington, DC: CSIS.

Delgado, N. G.

2010 "Agronegócio e agricultura familiar no Brasil: desafios para uma transformação democrática no meio rural." Paper presented to the Conference on Dynamics of Rural Transformation in Emerging Economies, New Delhi, April 14-16.

Delpeuch, T. 2008 L'analyse des transferts internationaux de politiques publiques: Un état de l'art. Sciences Po Questions de Recherche 27.

Dolowitz, D. and D. Marsh 1996 "Who learns what from whom: a review of the policy transfer literature." Political Studies 44: 343-357.

2012 “The future of policy transfer research." Political Studies Review 10: 339-345. 
Dowbor, L.

2011 "Intellectuals in a network: a new generation faces the challenges of development." Latin American Perspectives 38: 78-98.

Economist

2010 "Brazilian agriculture: the miracle of the cerrado." http://www.economist.com/ node/16886442 (accessed August 28, 2012).

Evans, M. and J. Davies

2002 "Understanding policy transfer: a multi-level, multi-disciplinary perspective." Public Administration 77: 361-385.

Freyre, Gilberto 1933 Casa-grande E senzala. Rio de Janeiro: Maia y Schmidt.

Goes, F., T. C. Patriota, and J. Tiburcio

2010 "Considerações sobre o potencial e os desafios de uma parceria Brasil-África para o desenvolvimento rural." Boletim de Economia e Políticas Internacional 53: 183-192.

Haibin, N.

2010 “Emerging global partnership: Brazil and China." Revista Brasileira de Política Internacional 53: 183-192.

Hirst, $\mathrm{M}$.

2010 As relações Brasil-África em ritmo de cooperação Sul-Sul. Rio de Janeiro: CEBRI.

Hirst, M., M. R. Lima, and L. Pinheiro

2010 "A política externa brasileira em tempos de novos horizontes e desafios." Nueva Sociedad, 22-41.

IBASE (Instituto Brasileiro de Análises Sociais e Econômicas)

1999 Avaliação dos programas de geração de emprego e renda. Democracia Viva, special edition.

Inoue, C. Y. and A. C. Vaz

2012 "Brazil as 'Southern donor': beyond hierarchy and national interests in development cooperation?" Cambridge Review of International Affairs 25: 507-534.

IPEA/ABC (Instituto de Pesquisa Econômica Aplicada/Agência Brasileira de Cooperação) 2010 Cooperação brasileiro para o desenvolvimento internacional 2005-2009. Brasília: IPEA/ABC.

Keohane, R.

1969 "Lilliputian's dilemmas: small states in international politics." International Organization $23(2)$.

Lima, M. R.

2005 "A política externa brasileira e os desafios da cooperação Sul-Sul." Revista Brasileira de Política Internacional 48 (1): 24-59.

Lima, M. R. and M. Hirst

2006 "Brazil as an intermediate state and regional power: action, choice, and responsibilities." International Affairs 82: 21-40.

Lopes, L.

2008 A cooperação técnica entre países em desenvolvimento da Agência Brasileira de Cooperação: O Brasil como doador. São Paulo: UNESP/UNICAMP/PUC-SP.

Macaulay, F.

2007 "Justice-sector and human rights reform under the Cardoso government." Latin American Perspectives 34 (5): 26-42.

Machado, A. P. C.

2009 A formulação da política comercial externa agrícola: Condicionantes internacionais e domésticos da transformação institucional do MAPA. Brasilia: Universidade de Brasília.

Magalhães, B. P.

2008 Política externa do Brasil lem agricultura: O papel da EMBRAPA na cooperaç0лo técnica. Brasília: Universidade de Brasília, Instituto de Ciências Políticas e Relações Internacionais.

Marques, S. F.

2005 "A imagem internacional do Brasil no governo Cardoso (1995-2002): uma leitura construtivista do conceito de potência média." Master's thesis, Pontificia Universidade Católica do Rio de Janeiro. http://www.maxwell.lambda.ele.puc-rio.br/Busca_etds.php?strSecao=res ultadoandnrSeq=6509@1 Acessed May 2012.

Marsh, D. and L. C. Sharman

2009 "Policy diffusion and policy transfer." Policy Studies 30: 269-288.

2011 A cooperação técnica do Brasil para a África. Brasília: MRE. 
Ncube, M., Lufumpa, C., and D. Vencatachellum

2011 "Brazil's economic engagement with Africa." Africa Economic Brief 2 (5). Nye, J.

2004 Soft Power: The Means to Success in World Politics. New York: Public Affairs.

OECD (Organization for Economic Cooperation and Development), AfDB (African Development

Bank), UNECA (United Nations Economic Commission for Africa), and UNDP (United Nations

Development Program)

2011 African Economic Outlook 2011: Africa and Its Emerging Partners. Paris: OECD.

Opera Mundi

2011 "Eleição de Graziano é vitória da política externa do Brasil, diz embaixador." June 26. $\mathrm{http}$ ///operamundi.uol.com.br/conteudo/noticias/13041/eleicao+de+graziano+e+vitoria+d a+politica+externa+do+brasil+diz+embaixador.shtml (accessed May 2012).

PDP (Política de Desenvolvimento Produtivo)

2010 Programa integração com a África: Relatório de acompanhamento de execução da agenda de ação. Brasília: PDP.

Perch, L., A. Bahalim, L. Cabral, and A. Shankland (eds.).

2012 The Role of South-South Cooperation in Inclusive and Sustainable Agricultural Development. Poverty in Focus 24. Brasília: International Policy Centre for Inclusive Growth.

Picolotto, E. L.

2006 Sem medo de ser feliz na agricultura familiar: O caso do movimento de agricultores em Constantina-RS. Santa Maria: Universidade Federal de Santa Maria.

Pino, B. A.

2009 Cooperación Sur-Sur: Innovació y transformación en la cooperación internacional. (accessed May 2012).

Porto, M. S. G. and D. E. A. Siqueira

1997 "A pequena produção no Brasil: entre os conceitos teóricos e as categorias empíricas," pp. 25-49 in M. S. G. Porto (ed.), Politizando a tecnologia no campo brasileiro: Dimensões e olhares. Rio de Janeiro: Relume Dumara.

Rosenau, J. N.

1990 "Justifying jailbreaks: the limits of contemporary concepts and methods," pp. 21-44 in Turbulence in World Politics: A Theory of Change and Continuity. Princeton: Princeton University Press.

Rowlands, D.

2008 Emerging Donors in International Development Assistance: A Synthesis Report. Ottawa: IDRC/ CRDI.

Sabourin, E.

2007 "Que política pública para a agricultura familiar no segundo governo Lula?" Sociedade e Estado 22: 715-751.

Schneider, $\mathrm{S}$.

2003 “Teoria social, agricultura familiar e pluriatividade." Revista Brasileira de Ciências Sociais 18 (51): 99-122.

Silva, Luiz Inácio Lula da

2010 “Discurso do Presidente da República, Luiz Inácio Lula da Silva, durante sesão de abertura da Cúpula Brasil-Comunidade Econômica dos Estados da África Ocidental (Cedeao), Ilha do Sal, Cabo Verde, 03/07/2010." http://www.itamaraty.gov.br/divulg/documentacao-diplomatica/ publicacoes/resenha-de-politica-exterior-do-brasil/resenhas/resenha-107 (accessed May 2012).

Slaughter, A. M.

2002 "Breaking out: The proliferation of actors in the international system," pp. 12-35 in Y. Dezalay and G. Bryant (eds.), Global Prescription: The Production, Exportation, and Importation of a New Legal Orthodoxy. Ann Arbor: University of Michigan Press.

Soule-Kohndou, F. A.

2010 Puissances émergentes et multilateralisme: Le cas de l'Afrique du Sud (1999-2008). Paris: L'Harmattan.

Teixeira, J. D.

2005 "Modernização da agricultura no Brasil: impactos econômicos, sociais e ambientais." Revista Eletrônica da Associação dos Geógrafos Brasileiros, Seção Três Lagoas 2 (2): 21-43. 
Tilly, C. and S. Tarrow

2008 Politique(s) du conflit: De la grève à la révolution. Paris: Presses de Sciences Po.

Vaz, A. C. and C. Y. A. Inoue

2007 Les économies émergentes et l'aide au développement international: Le cas du Brésil. http://www. idrc.ca/FR/Documents/cas-du-bresil.pdf (accessed May 2012).

Westney, E.

1987 Imitation and Innovation: The Transfer of Western Organizational Patterns ot Meiji Japan. Cambridge: Harvard University Press.

World Bank/IPEA (Instituto de Pesquisa Econômica Aplicada)

2011 Brasil e África Subsaariana: Parceria Sul-Sul para o crescimento. Brasília: IPEA. 